\title{
OBSERVATIONS ON THE PROTEOLYTIC ACTIVITY IN VITRO AT NEUTRAL REACTION OF GASTRIC JUICE FROM PATIENTS WITH SPRUE ${ }^{1}$
}

\author{
By HERBERT J. FOX 2 \\ (From the Department of Medicine, Duke University Medical School and Hospital, \\ Durham, N.C.)
}

(Received for publication December 22, 1948)

Previous investigators (1) have demonstrated the presence in normal human gastric juice of a protease which is active at neutral reaction. Certain properties were exhibited which distinguished the enzyme from pepsin and trypsin. Subsequent studies (2-4) showed that the protease and the so-called intrinsic factor of Castle possessed certain identical properties : both are removed by adsorption with Lloyd's reagent, both are unable to penetrate a semi-permeable membrane, they are not destroyed by Berkefeld filtration or exposure to alkali, but are destroyed by exposure to heat and are inhibited by an environment more acid than $\mathrm{pH}$ 3.5. Furthermore, it was found that this protease activity was absent or greatly diminished in patients with Addisonian pernicious anemia, but was normal in patients with pernicious tapeworm anemia.

The pathogenesis of the macrocytic anemia in sprue has aroused much speculation. Because it seemed important to determine whether or not the intrinsic factor was contained in the gastric juice of this disease, and because the gastric protease which is active at neutral reaction may be identical with Castle's intrinsic factor, it was decided to measure gastric protease activity at neutral reaction in sprue.

\section{METHODS}

The method was similar to that previously described (1), except for modifications noted below. Gastric juice was collected free from bile after stimulation with histamine and promptly filtered through gauze. The juice was brought to $\mathrm{pH} 10$ with sodium hydroxide and kept for 30 minutes at $40^{\circ} \mathrm{C}$, after which it was brought to $\mathrm{pH}$ 7.4. To $50 \mathrm{ml}$. of such materials were added $50 \mathrm{ml}$. of a 1 per cent neutral casein solution, the mixture ad-

1 Aided by grants from the John and Mary R. Markle Foundation, and the Duke University Research Fund.

2 Associate in Medicine, Department of Medicine, Duke Medical School. justed to $\mathrm{pH} 7.4$ and $2 \mathrm{ml}$. of toluol added. The mixture was incubated at $37.5^{\circ} \mathrm{C}$ for 24 hours, the $\mathrm{pH}$ remaining constant. The procedures used for the formol titration of amino nitrogen and for the determination of total filtrable nitrogen were those previously described $(1,2)$. Samples of the digests were taken immediately, at four hours, and 24 hours for formol titration. At the same time intervals, samples were removed and analyzed for the total amount of nitrogen not precipitable by 10 per cent trichloroacetic acid. The amount of total filtrable nitrogen and of amino nitrogen produced in 24 hours was calculated from these determinations. Proteolytic activity was judged from increases in filtrable nitrogen in milligrams per $100 \mathrm{ml}$. digest. The absence of active trypsin was shown by the lack of a significant increase in amino nitrogen.

\section{RESULTS}

From a large number of experiments the following facts were confirmed:

(1). The effect of incubation of normal human gastric juice with casein solution at $p H$ 7.4. The fasting contents from normal subjects were removed and discarded. Histamine phosphate 0.5 mgm. was injected intramuscularly and the gastric secretion collected during the next hour. Certain physical changes occurred when such gastric juice was incubated with an equal quantity of 1 per cent casein solution at $\mathrm{pH}$ 7.4. The digestion mixtures became chalky white. The trichloroacetic acid filtrates from these serial samples showed progressive increases in turbidity. Increases in the total nitrogen in the trichloroacetic acid filtrates occurred along with these physical changes.

Peptic activity is not manifest at neutral reactions, and above $\mathrm{pH} 8$ pepsin is destroyed rapidly by $\mathrm{OH}$ ions. Furthermore, it has been shown (5) that exposure to alkali at $\mathrm{pH} 10$ at $40^{\circ} \mathrm{C}$ for 30 minutes destroys from 70 to 80 per cent of trypsin in solution. There was no significant increase in amino nitrogen in our experiments. This suggests that trypsin and other erepsin-like enzymes of duodenal origin did not account for increase in 
filtrable nitrogen. The results of ten experiments on normal controls, which agree with previous reports, are shown in Table I.

That infection may have an inhibitory effect is suggested from determinations made on gastric juice obtained from patients at the time of an acute respiratory illness and following convalescence. The results of two such experiments are inclucled in Table I. This would indicate that the gastric protease is inhibited cluring an acute illness and that the inhibitory factor disappears following recovery.

(2). The effect of incubation of human gastric juice, collected from sprue, with casein solution at $p H$ 7.4. Collections of gastric juice from sprue patients and treatment with alkali before mixing with casein for digestion were performed in a fashion similar to that used on normal controls. The results of 11 of these experiments on sprue are shown in Table II. The gastric juice obtained from cases of sprue in remission showed progressive increases in filtrable nitrogen which compared closely to results in normal controls. On the other hand, the gastric juice from cases of sprue in relapse, with characteristic diarrhea, meteorism, steatorrhea, weight loss, glossitis, and anemia, showed a greatly diminished production of total filtrable nitrogen. Also, it is noteworthy that there was no significant increase in amino nitro-

TABLE I

Effect of incubation with equal quantity of 1 per cent casein solution at $37.5^{\circ} \mathrm{C}$ and $\mathrm{pH} 7.4$ of preparations of gastric juice

\begin{tabular}{|c|c|c|c|c|c|}
\hline \multirow[t]{2}{*}{$\begin{array}{c}\text { Experi- } \\
\text { ment } \\
\text { num- } \\
\text { ber }\end{array}$} & \multirow[t]{2}{*}{$\begin{array}{l}\text { Preparation and } \\
\text { reference to clin-- } \\
\text { ical observation }\end{array}$} & \multicolumn{2}{|c|}{$\begin{array}{l}\text { Increase in ni- } \\
\text { trogen in trichlo- } \\
\text { roacetic acid fil- } \\
\text { trates } \\
(\mathrm{mgm.per} 100 \\
\text { ml. digest })\end{array}$} & \multicolumn{2}{|c|}{$\begin{array}{l}\text { Increase in amino } \\
\text { nitrogen by for- } \\
\text { mol titration } \\
(\mathrm{mgm} \text {. per } 100 \\
\text { ml. digest })\end{array}$} \\
\hline & & 4 hours & 24 hours & 4 hours & 24 hours \\
\hline 11 & Control-normal & 37.5 & 59.3 & 1.6 & 1.8 \\
\hline 12 & gastric juice & 14.5 & 44.5 & 0.3 & 2.0 \\
\hline 13 & after incuba- & 31.0 & 42.5 & 0.8 & 1.0 \\
\hline 14 & tion $\mathrm{pH} 10$ & 36.4 & 54.7 & 0.4 & 0.7 \\
\hline 15 & $40^{\circ} \mathrm{C}$ for 30 & 32.8 & 48.0 & 0.2 & 0.6 \\
\hline 16 & minutes & 20.3 & 34.6 & 0.5 & 0.8 \\
\hline $17 a^{*}$ & & 4.2 & 21.0 & 0.0 & 0.1 \\
\hline $17 \mathrm{~b}^{*}$ & & 35.2 & 42.0 & 0.7 & 1.4 \\
\hline $18 \mathrm{a} \dagger$ & & 7.4 & 9.2 & 0.0 & 0.0 \\
\hline $18 \mathrm{~b} \dagger$ & & 28.8 & 36.0 & 0.6 & 0.8 \\
\hline
\end{tabular}

* Samples of gastric juice $17 \dot{a}$ and $17 \mathrm{~b}$ were from same donor. Sample $17 \mathrm{a}$ was collected during an episode of acute tonsillitis. Sample $17 \mathrm{~b}$ was collected one month later.

† Samples $18 \mathrm{a}$ and $18 \mathrm{~b}$ from same donor. Sample 18a collected during acute attack of sinusitis. Sample $18 \mathrm{~b}$ collected three weeks later.
TABLE, II

Effect of incubation with equal quantity of 1 per cent casein solution at $37.5^{\circ} \mathrm{C}$ and $\mathrm{pH} 7.4$ of preparations of gastric juice

\begin{tabular}{|c|c|c|c|c|c|}
\hline \multirow{2}{*}{$\begin{array}{l}\begin{array}{c}\text { Experi- } \\
\text { ment } \\
\text { num- } \\
\text { ber }\end{array} \\
30 \\
31 a^{*} \\
32 \\
33 \\
34\end{array}$} & \multirow{2}{*}{$\begin{array}{l}\begin{array}{c}\text { Preparation and } \\
\text { reference to clin- } \\
\text { ical observation }\end{array} \\
\text { Sprue-relapse- } \\
\text { gastric juice } \\
\text { after incuba- } \\
\text { tion pH } 10, \\
40^{\circ} \mathrm{C} \text { for } 30 \\
\text { minutes }\end{array}$} & \multicolumn{2}{|c|}{$\begin{array}{l}\text { Increase in ni- } \\
\text { trogen in trichlo- } \\
\text { roacetic acid fil- } \\
\text { trates } \\
(\mathrm{mgm.} \text { per } 100 \\
\text { ml. digest })\end{array}$} & \multicolumn{2}{|c|}{$\begin{array}{l}\text { Increase in amino } \\
\text { nitrogen by for- } \\
\text { mol titration } \\
(\mathrm{mgm} . \text { per } 100 \\
\text { ml. digest })\end{array}$} \\
\hline & & $\begin{array}{c}\text { + hours } \\
12.0 \\
7.4 \\
12.0 \\
2.7 \\
4.8\end{array}$ & $\begin{array}{c}2+\text { hours } \\
13.6 \\
23.2 \\
21.0 \\
22.6 \\
14.3\end{array}$ & $\begin{array}{c}+ \text { hours } \\
0.0 \\
0.0 \\
0.6 \\
0.4 \\
0.2\end{array}$ & $\begin{array}{c}2.7 \text { hours } \\
0.4 \\
0.2 \\
1.6 \\
0.8 \\
1.4\end{array}$ \\
\hline $\begin{array}{l}31 b^{*} \\
35 \\
36 \\
37 \dagger \\
38 \\
39\end{array}$ & $\begin{array}{l}\text { Sprue-remis- } \\
\text { sion-gastric } \\
\text { juice, after } \\
\text { incubation } \\
\text { pH } 10,40^{\circ} \mathrm{C} \\
\text { for } 30 \mathrm{~min}- \\
\text { utes }\end{array}$ & $\begin{array}{l}40.5 \\
49.7 \\
21.4 \\
18.2 \\
32.0 \\
22.5\end{array}$ & $\begin{array}{l}47.6 \\
59.0 \\
55.0 \\
36.7 \\
49.0 \\
48.6\end{array}$ & $\begin{array}{l}0.0 \\
0.0 \\
0.0 \\
1.6 \\
0.2 \\
0.8\end{array}$ & $\begin{array}{l}0.4 \\
1.4 \\
0.7 \\
1.8 \\
0.8 \\
1.2\end{array}$ \\
\hline
\end{tabular}

* Samples of gastric juice $31 \mathrm{a}$ and $31 \mathrm{~b}$ were obtained from the same donor. Sample $31 \mathrm{~b}$ was obtained five months later during remission.

† Case 37 had a-chlorhydria.

gen. Experiments 31a and 31b noted in Table II were performed on the same patient during a period of relapse and remission respectively. These data would indicate that the gastric protease is distinguishably less during the relapse stage.

\section{DISCUSSION}

In the majority of sprue patients, gastric secretion was obtained without difficulty in a one-hour period. During the stage of severe relapse there was usually hypochlorhydria and a marked reduction in rate of secretion and in proteolytic activity at neutral reaction. Such patients were observed again and tests repeated six months after treatment had produced remission, and they then showed a return to normal in all these functions. These data suggest that intrinsic factor activity may also be reduced in the gastric secretions of persons with sprue in relapse.

Attempts were made to do a biologic assay of the gastric secretions from these patients in relapse to cletermine the presence or absence of intrinsic factor. Our efforts to collect sufficient gastric juice for daily feeding experiments failed. However, previous investigators (6) have performed a biologic assay on gastric secretions from a case of sprue. Apparently, they demonstrated the absence of intrinsic factor from the gastric contents of a 
case of sprue in relapse by feeding daily collections of gastric juice mixed with beef muscle to a case of Addisonian pernicious anemia.

It has been stated ( 7 ) that the deficiency in sprue may come about in a number of ways, among which are (1) a deficiency of extrinsic factor, (2) a defect of gastric digestion resulting from lack of intrinsic factor, and (3) defective absorption from the intestinal tract.

The mal-absorption from the small intestine in patients during relapse can be demonstrated with great frequency and certainly is a major cause of the sprue syndrome. Defective absorption of fats, fat-soluble vitamins, calcium, and carbohydrates can be commonly demonstrated. Patients with severe diarrhea will also show faulty assimilation of protein.

Dietary histories on our sprue patients have not shown any correlation between the ingestion of meat products, or other sources of extrinsic factor, and the incidence of anemia. When fed adequate amounts of beef muscle, the patients in relapse failed to obtain a remission. Subsequently, they made a satisfactory response to injectable liver extract or folic acid.

The data presented in this paper support the concept that a defect in gastric digestion may be important to the occurrence of macrocytic anemia in sprue; though whether such a defect is primary or secondary to gastro-intestinal mal-absorption and chronic debility can not be ascertained. Data reported here show that acute infection can lower the value of the proteolytic activity at neutral reaction to a very low level.

The fact that the anemia of sprue is macrocytic and improved by liver does not mean that a primary deficiency of gastric origin is present. This is well shown by the pernicious tapeworm anemia.

It can only be said that the protease activity of the gastric juice is lessened in sprue in relapse and normal in remission.

\section{CONCLUSIONS}

1. When equal quantities of normal human gastric juice and 1 per cent casein solution are incubated at $37.5^{\circ} \mathrm{C}$ and $\mathrm{pH} 7.4$, there is a progressive increase in filtrable nitrogenous substances. The proteolysis was not considered to result from pepsin because the activity was maximal at $\mathrm{pH}$ 7.4. Also, since there was no significant increase in amino nitrogen within 24 hours, together with the persistent increase in total filtrable nitrogen after exposure to $\mathrm{pH} 10$, it is considered that the proteolysis was not due to trypsin.

2. The proteolytic activity of the gastric enzyme at neutral reaction, is present to a normal degree in cases of sprue in remission. It is greatly diminished in cases of sprue in relapse. The absence of proteolytic activity in cases of pernicious anemia suggests that the deficiency of intrinsic factor so characteristic of pernicious anemia, may be present in sprue in relapse.

3. In two non-anemic normal subjects, it appears that infection inhibited this type of proteolysis to a considerable degree.

\section{BIBLIOGRAPHY}

1. Taylor, F. H. L., Castle, W. B., Heinle, R. W., and Adams, M. A., Correlation of in vitro activity of normal human gastric juice on casein at $\mathrm{pH} 7.4$ with gastric intrinsic factor. Proc. Soc. Exper. Biol. \& Med., 1937, 36, 566.

2. Taylor, F. H. L., Castle, W. B., Heinle, R. W., and Adams, M. A., Observations on the etiologic relationship of achylia gastrica to pernicious anemia. VII. Resemblances between the proteolytic activity of normal human gastric juice on casein in neutral solution and the activity of the intrinsic factor. J. Clin. Invest., 1938, 17, 335.

3. Gessler, C. J., Dexter, S. O., Adams, M. A., and Taylor, F. H. L., Observations on the etiologic relationship of Achylia Gastrica to pernicious anemia. VIII. Further studies of the proteolytic activity of normal human gastric juice in vitro. J. Clin. Invest., 1940, 19, 225.

4. von Bonsdorff, B., On the proteolytic activity in vitro at neutral reaction of gastric juice from patients with cryptogenic pernicious anemia and with pernicious anemia due to Diphyllobothrium latum. Acta. med. Scandinav., 1940, 105, 540.

5. Northrop, J. H., The inactivation of trypsin. III. Spontaneous inactivation. J. General Physiol., 1922, 4, 261.

6. Castle, W. B., Heath, C. W., and Strauss, M. B., Observations on the etiologic relationship of achylia gastrica to pernicious anemia. IV. A biologic assay of the gastric secretion of patients with pernicious anemia having free hydrochloric acid and that of patients without anemia, or with hypoc̀hromic anemia having no free hydrochloric acid, and of the role of intestinal impermeability to hematopoietic substances in pernicious anemia. Am. J. M. Sc., 1931, 182, 741.

7. Hanes, F. M., Sprue; in: Practice of Medicine, edited by Tice, Frederick. W. F. Prior Co., Hagerstown, Md. 1943, Vol. 4, 171. 